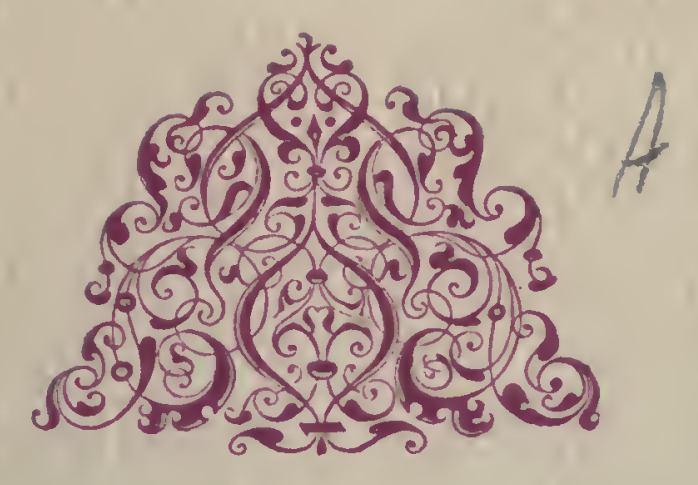

\title{
Renaissance and
}

Reformation

\section{nim}

\section{VOLUME VÍ $197^{\circ}$ NUMBER I}

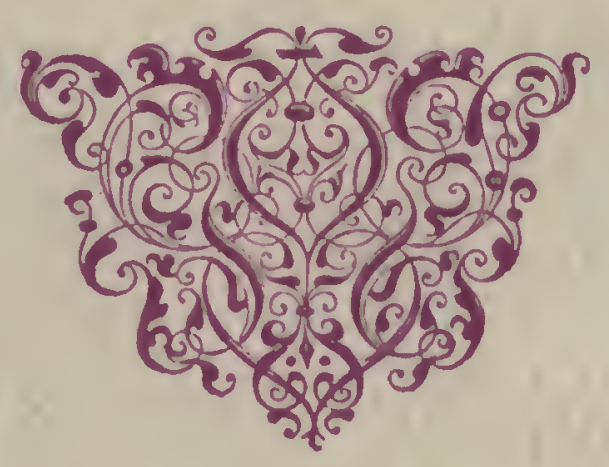


Renaissance and Reformation is published 3 times a year (September - June)

(c) the University of Toronto Renaissance and Reformation Colloquium the Victoria University Centre for Renaissance and Reformation Studies (CRRS), 1971

\author{
Editor \\ Julius A. Molinaro \\ Associate Editor \\ M. R. Maniates \\ Editorial Assistant \\ Walter Dedi \\ Editorial Committee \\ Co-Chairmen \\ C. Edward Rathé (York University) \\ H. R. Secor \\ J. M. Estes \\ V. E. Graham \\ F. J. D. Hoeniger \\ J. K. McConica \\ Marshall McLuhan \\ John Meyer (McMaster University) \\ J. H. Parker \\ Brayton Polka (York University) \\ Patricia Vicari
}

Subscription price is $\$ 2.50$ per year. Manuscripts should be accompanied by a self-addressed, stamped envelope and follow the revised edition of the MLA Style Sheet.

Manuscripts should be addressed to:

The Editor

Renaissance and Reformation

Dept of Italian \& Hispanic Studies

University of Toronto

Toronto 5, Canada

All communications, including notices of changes of address, enquiries and subscriptions should be sent to:

Leslie T. McCormick

Business Manager

Renaissance and Reformation

Erindale College

3359 Mississauga Rd.

Clarkson, Ontario, Canada 


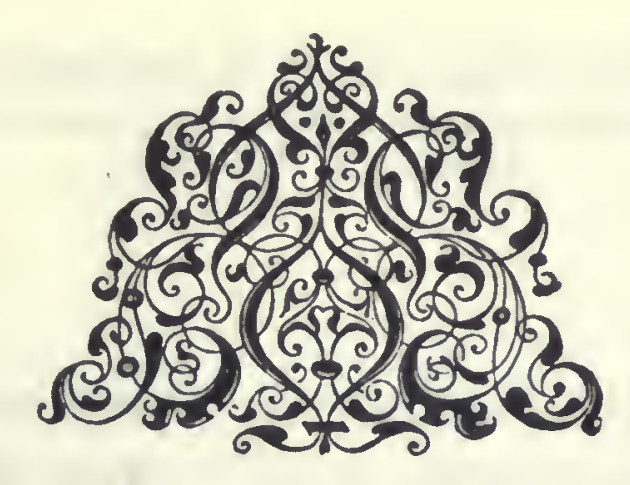

\section{Contents}

3

The Ciceronian Program in Pulpit and in Literary Criticism

MARSHALL MCLUHAN

8

The Letters of Bernardino Pino da Cagli: Christian Humanism in the Late Renaissance WALTER J. TEMELINI

10

BOOK REVIEWS

GUY HAMEL: Frances A. Yates, Theatre of the World

J. KORNBERG

Peter Burke, The Renaissance Sense of the Past (Documents of Modern History)

J. H. PARKER

Elmer M. Blistein, ed., The Drama of the Renaissance: Essays for Leicester Bradner MICHAEL UKAS

Douglas Radcliff-Umstead, The Birth of Modern Comedy in Renaissance Italy PETER V. MARINELLI

Richard Cody, The Landscape of the Mind: Pastoralism and Platonic Theory in

Tasso's Aminta and Shakespeare's Early Comedies

SUSANNA N. PETERS

Joan Gadol, Leon Battista Alberti: Universal Man of the Early Renaissance

MADDALENA KUITUNEN

Anthony Molho, ed.: Social and Economic Foundations of the Italian Renaissance

18

Report

H. R. SECOR F. D. HOENIGER

20

Announcements

Renaissance and Reformation VOLUME VII 1970 NUMBER 1

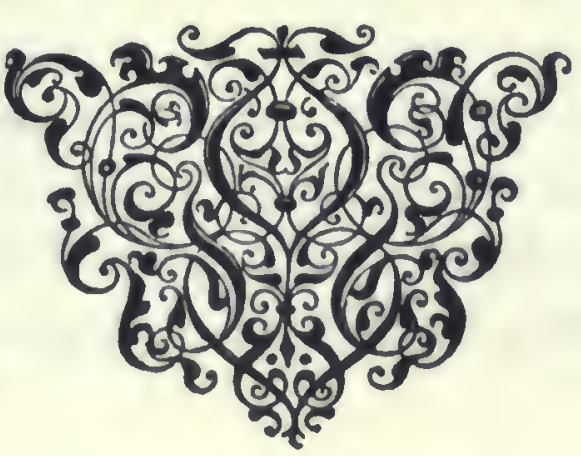

